\title{
Partisipasi Masyarakat Lokal Dalam Pengelolaan Daya Tarik Wisata Pantai Pandawa Di Desa Adat Kutuh Kabupaten Badung
}

Gusti Made Sugiwinata a,1, Ida Bagus Suryawan a,2

1gustimadesugiwinata@gmail.com,2idabagussuryawan@unud.ac.id

a Program Studi S1 Destinasi Pariwisata, Fakultas Pariwisata,Universitas Udayana, Jl. Dr. R. Goris, Denpasar, Bali 80232 Indonesia

\section{Abstract}

This research discusses about Participation of Local Community in the Management of Tourist Attraction of Pandawa Beach at the Customary Village of Kutuh. The research aims to discuss the potential of tourist attraction of Pandawa beach, which has been developed by the authorized management, as well as the participation of local community of Kutuh customary village. Further, the management of tourist attraction of Pandawa Beach is described according to five elements: tourism industry and typology of participation and characteristic of the community.

Method used is descriptive qualitative. Data was collected by way of observation, structured interview, literature study and documentation. Later data was analyzed with informant setting technique and purpose sampling technique. Based on the result of discussion can be suggested that local community participation in the management of tourist attraction of Pandawa beach namely the provision of qualifies natural resources, recruitment of employess for tourist attraction of Pandawa beach preferring local population to increase the economy of community of Kutuh customary village.

Keywords: Public Participation Management

\section{PENDAHULUAN}

Bali merupakan pulau yang memiliki potensi industri pariwisata terbesar di Indonesia. Selain Bali merupakan pulau seribu pura, Bali juga terkenal dengan keindahan alam dan budayanya. Salah satu daya tarik wisata yang terdapat di Bali adalah Pantai Pandawa.

Pantai Pandawa adalah salah satu industri pariwisata yang terletak di Desa Adat Kutuh, Kecamatan Badung. Dahulu sebelum dikenal sebagai Pantai Pandawa, pantai ini tidak pernah dijamah oleh para wisatawan baik lokal maupun mancanegara. Hal ini dikarenakan dahulu belum adanya akses jalan menuju pantai pandawa mengingat pantai ini sangat berada di bawah curam tebing. Dulunya pantai ini disebut dengan Pantai Melasti, karena pantai ini digunakan oleh masyarakat sekitar untuk kegiatan upacara agama yang bernama upacara Melasti. Selain itu pantai ini dulunya digunakan sebagai masyarakat sekitar untuk berbudi daya rumput laut dimana masyarakat sekitar sebagaian besar bekerja sebagai petani rumput laut. Di sisi lain pantai ini juga terkenal dengan istilah Secret Beach oleh tamu mancanegara yang pertama kali mengetahui daya tarik wisata pantai ini. Karena letaknya yang tersembunyi namun memiliki potensi industri pariwisata yang sangat potensial, Sampai akhirnya pantai ini lebih dikenal oleh para wisatawan. Hingga akhirnya pantai ini ditetapkan dengan nama Pantai Pandawa oleh pihak pengelola karena proses perkembangan serta konsep obyek wisata ini hampir sama dengan kisah Kitab Mahabrata.

Penelitian ini bertujuan untuk mengetahui konsep manajemen pengelolaan daya tarik wisata Pantai Pandawa yang dilakukan oleh pihak manajemen pengelola Pantai Pandawa hingga bisa berkembang pesat seperti saat ini serta bagaimana bentuk partisipasi masyarakat desa adat kutuh terhadap pengelolaan daya tarik wisata Pantai Pandawa ini. Hasil penelitian ini diharapakan mampu dijadikan bahan masukan, saran serta informasi bagi pihak manajemen pengelola dan masyarakat desa adat kutuh dalam mengelola dan mengembangkan daya tarik wisata Pantai Pandawa ini.

\section{TINJAUAN PUSTAKA}

Konsep dan teori analisis yang digunakan dalam penelitian ini antara lain : konsep pengelolaan (Leiper, 1990), konsep partisipasi masyarakat (Cohen dan Uphoff, 1997), konsep mengenai tipologi partisipasi masyarakat (Jain, 2000), konsep definisi pariwisata (Pendit, 2002), konsep daya tarik wisata (Fandeli, 1995), konsep pengelolaan daya tarik wisata (James J.Spillane, 1982) konsep partisipasi masyarakat merupakan keikutsertaan atau keterlibatan sekelompok orang ke dalam situasi sosial tertentu dimana suatu kelompok ini melakukan suatu kegiatan dan memiliki peran serta fungsi untuk 
mengelola. Pada penelitian ini dipergunaka analisis Deskriptif Kualitatif yang merupakan salah satu metode yang memiliki sifat deskriptif dan lebih menggunakan analisis pendekatan induktif dimana jenis metode kualitatif ini tidak menggunakan metode statistik atau cara perhitungan angka.

\section{METODE PENELITIAN}

Jenis data yang digunakan dalam penelitian ini adalah data kualitatif dan data kuantitatif. Sumber data yang digunakan pada penelitian ini yaitu data primer dan data sekunder. Teknik Pengumpulan data dilapangan dilakukan dengan cara obeservasi, wawancara terstruktur, studi kepustakaan, dokumentasi. Teknik Penentuan Informan pada penelitian ini menggunakan purposive sampling yaitu teknik pemilihan narasumber yang akurat dan benar benar mengetahui faktor kondisi eksternal dan internal kegiatan pengelolaan Pantai Pandawa. Teknik analisis data yang digunakan adalah analisis data deskriptif kualitatif dengan menggunakan konsep pengelolaan serta konsep tipologi partisipasi masyarakat dimana memaparkan dengan rinci hasil penelitian ini berdasarkan permasalah yang diteliti dari sumber data yang diperoleh.

\section{HASIL DAN PEMBAHASAN}

Pantai Pandawa adalah salah satu daya tarik wisata yang memiliki keindahan tebing tebing yang mengeliling akses jalan menuju pantai yang sangat indah dan bersih dengan pasir putihnya serta patung Panca pandawa yang terdapat di dalam tebing. Pantai Pandawa ini terletak di Desa Kutuh, Banjar Dinas Pantigiri, Kabupaten Badung.

Pantai Pandawa ini dikelola oleh pihak manajemen pengelola yang berasal dari masyarakat Desa Adat Kutuh yang dipilih langsung oleh masyarakat Desa Kutuh. Pihak manajemen pengelola ini memiliki struktur organisasi yang mempunyai tugas dan tanggung jawab di masing masing bidang nya yang didasari dasar hukum pengelolaan yang ada. Pihak manajemen pengelola serta masyarakat ini yang mengelola dan mengupayakan perkembangan daya tarik wisata Pantai Pandawa ini. Peran partisipasi masyarakat lokal sangat penting di dalam pengembangan daya tarik wisata Pantai Pandawa.

\subsection{Daya Tarik Wisata Pantai Pandawa.}

Unsur - unsur industri pariwisata yang sangat penting yang terdapat di daya tarik wisata Pantai Pandawa ini meliputi :

1. Atraksi Pantai Pandawa

Atraksi wisata yang terdapat di pantai pandawa meliputi : Wedding party, prewedding shooting, kegiatan olahraga volly pantai, kegiatan out bound serta pementasan seni budaya seperti tari kecak.

2. Aksesibilitas Pantai Pandawa

Aksesbilitas yang dimaksudkan dalam hal ini meliputi akses jalan masuk yang sedang dibangun serta ditata untuk mempermudah memasuki daya tarik wisata Pantai Pandawa.

3. Fasilitas

\section{a. Sarana}

Sarana yang telah disediakan oleh pihak pengelola seperti : Jasa Transportasi, Travel Agent Wisata serta Biro Perjalanan Wisata.

b. Prasarana

Prasarana yang sudah disediakan oleh pihak manajemen pengelola pantai pandawa demi kenyamanan para wisatawan yang berkunjung meliputi : lahan parkir, instalasi listrik, toilet, kantin atau warung serta pihak pengamanan daya tarik wisata Pantai Pandawa

4. Infrastruktur Pantai Pandawa

Infrastruktur yang telah dibangun dan dikembangan sebagai daya tarik wisata Pantai Pandawa ini yaitu : penataan jalan, pembuatan candi bentar di pintu masuk daya tarik wisata Pantai Pandawa, penataan tebing tebing serta tulisan PANTAI PANDAWA yang diletakan ditengah tengah tebing serta Patung Panca Pandawa yang merupakan ikon dari daya tarik wisata Pantai Pandawa.

5. Hospitalitas

Disediakannya stand yang dijaga oleh Guide (Pihak Pengelola) khusus untuk menyambut para wisatawan yang berkunjung dilengkapi dengan brosur serta buku yang membahas tentang Pantai Pandawa. 


\subsection{Potensi Pantai Pandawa}

Potensi potensi yang dimiliki daya tarik wisata pantai pandawa yang dapat dijadikan sebagai daya tarik para wisatawan yang berkunjung meliputi :

1. Potensi Tebing

Penataan tebing yang tinggi yang mengelilingi dari akses jalan masuk menuju pantai sangat dinikmati pemandangan oleh para wisatawan. Potensi ini juga dikembangkan dengan mengadakan kegiatan olahraga Paragliding dan Panjat Tebing.

2. Potensi Pesisir dengan Pasir Putih

Selain pantai yang airnya masih bersih dan berwarna biru, pantai ini juga dikelilingi oleh pasir yang berwarna putih yang menambah nilai keindahan Pantai Pandawa.

3. Potensi Perairan

Potensi ini dibagi menjadi 3 ( tiga ) zona berdasarkan pemanfaatannya yang meliputi :

a. Zona Budidaya Rumput Laut

Zona ini diperuntukkan bagi petani rumput laut yang mengembangkan budidaya rumput laut. Tetapi saat ini jumlah zona ini mulai berkurang dan sulit untuk dijumpai di daya tarik wisata Pantai Pandawa.

b. Zona Public Area

Dimana zona ini diperuntukkan bagi para wisatawan yang hendak menikmati pemandangan dan keindahan pantai pandawa sambil beristirahat atau bisa juga bermain pasir di tepi pantai.

c. Zona Konservasi

Zona ini terletak di sisi barat pantai yang konsepnya membangun kawasan pelestarian budidaya terumbu karang yang dimaksudkan untuk perlindungan serta pelestarian terumbu karang.

4. Potensi Patung Pandawa

Potensi ini merupakan ikon dari daya tarik wisata Pantai Pandawa, dimana diangkat dari kisah Kitab Mahabrata. Adapun tokohnya meliputi : Yudistira, Bima, Arjuna, Nakula, Sahadewa.Terdapat juga patung Dewi Kunti serta Patung tikus yang diambil juga dari kisah Mahabrata.

\subsection{Upaya Pengelolaan dalam Memperkenalkan Pantai Pandawa.}

Strategi pemasaran yang dilakukan dalam upaya memperkenalkan daya tarik wisata Pantai Pandawa ini sebagai berikut :

a. Pihak Manajemen Pengelola

Strategi yang dilakukan dalam memperkenalkan daya tarik wisata Pantai Pandawa ini dengan melalui media cetak dan media elektronik.

Media cetak yang dimaksudkan disini yaitu pembuatan brosur brosur, buku panduan wisata mengenai Pantai Pandawa yang akan dibagikan kepada para wisatawan yang berkunjung, Sehingga secara tidak langsung dapat memperluas informasi mengenai daya tarik wisata Pantai Pandawa.

Pihak pengelola menggunakan media sosial facebook yang bernama Pesona Bahari Pandawa yang mengulas tentang daya tarik wisata Pantai Pandawa.

b. Pihak Masyarakat.

Masyarakat

biasanya

menginformasikan pantai pandawa ini melalui mulut ke mulut kepada kerabat atau saudara mereka yang berada di Bali maupun luar Bali. Selain melalui informasi lisan, masyarakat juga menggunakan media sosial seperti facebook atau instagram untuk memperkenalkan keindahan daya tarik wisata Pantai Pandawa melalui mengunggah foto yang mereka buat saat mengunjungi daya tarik wisata Pantai Pandawa, Dimana semua orang dapat mengakses melalui internet.

c. Pemerintah Daerah

Peran pemerintah daerah dalam memperkenalkan daya tarik wisata Pantai Pandawa yaitu memperkenalkan secara lisan kepada kerabat dan keluarga, selain itu pengadaan suatu kegiatan event yang diselenggarakan di daya tarik wisata Pantai Pandawa Melalui media elektronik. Pemerintah membuat situs internet yang mengulas tentang pantai pandawa yang dapat diakses melalui internet http : www.kutaselatan.badungkab.go.id. 


\subsection{Analisis Deskriptif Kualitatif terhadap Partisipasi Masyarakat Dalam Pengelolaan Daya Tarik Wisata Pantai Pandawa.}

Pada penelitian ini bentuk partisipasi masyarakat diambil berdasarkan teori tipologi partisipasi masyarakat ( Jain, 2002). Sebab berdasarkan penelitian lapangan teori ini yang paling mendekati dengan kerja nyata di daya tarik wisata Pantai Pandawa. Berikut bentuk bentuk partisipasi masyarakat berdasarkan unsur unsur dari industri pariwisata berdasarkan konsep pengelolaan meliputi :

1. Atraksi

a. Planning

Perencanaan ini merupakan bentuk partisipasi interaktif. Yang dimaksud dalam hal ini pihak pengelola berencana mengundang masyarakat dalam pembahasan program dari kegiatan daya tarik wisata Pantai Pandawa.

b. Directing

Pengarahan ini merupakan bentuk partisipasi dalam bentuk konsultasi. Dimana adanya pertemuan dalam bentuk musyawarah serta pengarahan antara pihak pengelola dengan masyarakat berdasarkan rencana yang telah dibuat.

c. Organizing

Pengorganisasian ini merupakan bentuk partisipasi fungsional. Yaitu pembentukan suatu organisasi atau kelompok yang berfungsi mewakili dalam menangani masalah yang ada.

d. Controling

Pengawasan ini merupakan bentuk partisipasi penggerakan pribadi. Dimana dari pengawasan ini diharapkan semua kegaiatan atraksi dapat berjalan lancar.

2. Fasilitas

\section{a. Planning}

Perencanaan ini merupakan bentuk partisipasi interaktif. Yaitu interaksi antara pihak pengelola dengan masyarakat dalam merencanakan penyusunan fasilitas yang akan disediakan.

b. Directing

Pengarahan ini merupakan bentuk partisipasi dalam bentuk konsultasi, dimana keikutsertaan kedua belah pihak dalam pengarahan tata letak fasilitas daya tarik wisata yang akan dipenuhi.

c. Organizing

Pengorganisasian ini merupakan bentuk partisipasi fungsional. Pembentukan kelompok kelompok setiap jenis bidang fasilitas dalam mengkoordinasi setiap bagian.

d. Controling

Pengawasan ini merupakan bentuk partisipasi penggerakan pribadi. Pengawasan ini sangat penting dilakukan bersama sama untuk menjaga fasilitas yang sudah disediakan dari resiko kehilangan atau kerusakan.

3. Infrastruktur

\section{a. Planning}

Perencanaan ini merupakan bentuk partisipasi interaktif. Yaitu diskusi antara kedua belah pihak serta ikut serta peran pemerintah dalam perancangan infrastruktur yang akan dikembangkan di daya tarik wisata Pantai Pandawa.

b. Directing

Pengarahan ini merupakan bentuk partisipasi dalam bentuk konsultasi. Adanya kegiatan konsultasi dalam mengarahkan hal yang masih diperlukan dalam pengembangan infrastruktur daya tarik wisata Pantai Pandawa ini.

c. Organizing

Pengorganisasian ini merupakan bentuk partisipasi fungsional. Pembahasan pembentukan kelompok mengenai tata letak infrastruktur yang akan dipasang.

d. Controling

Pengawasan ini merupakan bentuk partisipasi penggerakan pribadi. Partisipasi ini sangat penting dilakukan oleh kedua belah pihak untuk kelancaran operasional dan terhindar dari resiko yang tidak diinginkan.

4. Aksesibilitas

\section{a. Planning}

Perencanaan ini merupakan bentuk partisipasi interaktif. Pembahasan 
ini mengenai perancangan pembangunan akses jalan menuju daya tarik wisata Pantai Pandawa.

b. Directing

Pengarahan ini merupakan bentuk partisipasi dalam bentuk konsultasi. Yaitu dalam partisipasi ini membahas tentang pengarahan kepada pemda yang akan membantu dalam pembuatan akses jalan serta pembangunan candi bentar

c. Organizing

Pengorganisasian ini merupakan bentuk partisipasi fungsional. Hal ini dimaksudkan yaitu pembahasan mengenai pembentukan kelompok atau bagian dari batas akses jalan masuk, batas penempatan candi bentar serta jalan parkir daya tarik wisata pantai pandawa.

d. Controling

Pengawasan ini merupakan bentuk partisipasi aktif, Dimana seluruh pihak baik pihak majemen pengelola, pihak masyarakat serta pemerintah daerah ikut serta dalam mengawasi pembangunan aksesbilitas ini yang dimana bisa bermanfaat dalam hal efisiensi waktu.

5. Hospitalitas

a. Planning

Perencanaan ini merupakan bentuk partisipasi interaktif. Diadakannya pembahasan interaktif antara pihak pengelola dengan pihak masyarakat dalam pemberdayaan keramahtamahan untuk peningkatan jumlah kunjungan para wisatawan.

b. Directing

Pengarahan ini merupakan bentuk partisipasi dalam bentuk konsultasi. Diadakannya konsultasi ini untuk membahas arahan dengan disediakan nya stand yang bertugas menyambut para wisatawan yang datang berkunjung ke obyek wisata Pantai Pandawa.

c. Organizing

Pengorganisasian ini merupakan bentuk partisipasi fungsional.
Dalam partisipasi ini dibentuk kelompok yang bertugas sebagai guide (pemandu wisata) yang menjamu serta memperkenalkan para wisatawan yang berkunjung ke obyek wisata pantai pandawa, Selain itu juga penyediaan brosur serta buku wisata mengenai Pantai Pandawa.

d. Controling

Pengawasan ini merupakan bentuk partisipasi aktif. Kegiatan ini sangat penting dilakukan untuk mengetahui kualitas pelayanan yang selama ini telah berlangsung, Sehingga dapat memperbaiki kinerja pengelolaan yang masih belum kompeten.

\section{SIMPULAN DAN SARAN SIMPULAN}

Pengelolaan daya tarik wisata Pantai Pandawa dipengaruhi oleh faktor yang meliputi potensi Pantai Pandawa seperti potensi tebing , potensi pesisir dengan pasir putih, potensi perairan yang dibagi menjadi 3 ( tiga ) zona yaitu zona budidaya rumput laut, zona public area, zona konservasi, potensi patung pandawa.

Selain potensi faktor yang mempengaruhi kinerja pengelolaan yaitu pihak manajemen pengelola yang telah terorganisasi dan struktur yang memiliki tugas serta tanggung jawab sesuai dengan bidangnya. Daya tarik wisata pantai pandawa ini berada dibawah naungan BUMDA (Bhaga Utsaha Manunggal Desa Adat).

Bentuk partisipasi masyarakat dilihat dari unsur unsur industri pariwisata berdasarkan komponen dari pengelolaan meliputi :

1. Atraksi

a. Perencanaan di level Partisipasi Interaktif.

b. Pengarahan di level Partisipasi dalam bentuk konsultasi.

c. Pengorganisasian di level Partisipasi fungsional

d. Pengawasan di level Partisipasi Penggerakkan Pribadi.

2. Fasilitas

a. Perencanaan di level Partisipasi Interaktif.

b. Pengarahan di level Partisipasi dalam bentuk konsultasi. 
c. Pengorganisasian di level Partisipasi fungsional.

d. Pengawasan di level Partisipasi Penggerakkan Pribadi.

3. Infrastruktur
a. Perencanaan di level Partisipasi Interaktif.
b. Pengarahan di level Partisipasi dalam bentuk konsultasi..
c. Pengorganisasian di level Partisipasi fungsional.
d. Pengawasan di level Partisipasi Penggerakkan Pribadi.

4. Aksesibilitas
a. Perencanaan di level Partisipasi Interaktif.
b. Pengarahan di level Partisipasi dalam bentuk konsultasi.
c. Pengorganisasian di level Partisipasi fungsional.
d. Pengawasan di level Partisipasi Aktif.

5. Hospitalitas
a. Perencanaan di level Partisipasi Interaktif.
b. Pengarahan di level Partisipasi dalam bentuk konsultasi.
c. Pengorganisasian di level Partisipasi fungsional.
d. Pengawasan di level Partisipasi Penggerakkan Pribadi.

\section{SARAN}

Berdasarkan hasil dari pembahasan dan kesimpulan dari penelitian ini, maka penulis dapat memberikan saran sebagai berikut :

1. Perekrutan tenaga kerja lebih diutamakan yang berasal dari desa adat kutuh baik dalam bidang pengelolaan ataupun industri perdagangan barang atau jasa di daya tarik wisata Pantai Pandawa. Sehingga secara tidak langsung dapat mengurangi tingkat pengangguran di desa kutuh dan meningkatan perekonomi masyarakat desa kutuh.

2. Diadakannya pelatihan atau kursus kursus terhadap tenaga kerja baik yang sudah kompeten atau yang belum kompeten untuk meningkatkan kualitas sumber daya manusia yang berkecimpung di dalam kegiatan operasional daya tarik wisata Pantai Pandawa.

3. Diperlukannya pengembangan ide, gagasan atau inovasi baru pada pengelolaan obyek wisata Pantai Pandawa, untuk bisa meningkatkan kualitas daya tarik wisata Pantai Pandawa.

Daftar Pustaka:

Ach. Wazir Ws., et al., ed,1999. Panduan Penguatan Manajement Lembaga Swadaya Masyarakat.Jakarta : Sekretariat Bina Desa dengan dukungan AUS AID melalui Indonesia HIV / AIDS and STD Prevention and Care Project.

Arikunto, S., 2010. Prosedur Penelitian : Suatu Pendekatan Praktis.Jakarta : Rineka Cipta.

Black, J.A. dan Champion, D.J., 1992. Metode dan Masalah Penelitian Sosial. Bandung: SD, Eresco.

Bhaga Utsaha Manunggal Desa Adat ( Bumda ). 2016. Laporan RKPB. Badung : BUMDA.

BPS Provinsi Bali, 2015. Statistik Pariwisata Bali. Denpasar : BPS Bali.

Cohen and Uphoff, 1977. Pural Development Participation Cornel University. New York : Cornel University RDCCIS.

Dewi, Oktami. 2013. Partisipasi Masyarakat Dalam Pengembangan Objek Wisata Bahari Di Pulau Kapoposang Kabupaten Pangkajene Dan Kepulauan. Makassar : Universitas Hasanudin.

Fandeli, C., 1995.Dasar - Dasar Kepariwisataan Alam. Yogyakarta : Liberty.

Gelgel, I Putu, 2009.Industri Pariwisata Indonesia Dalam Globalisasi Perdagangan Jasa (GATS - WTO), Implikasi Hukum dan Antisipasinya. Bandung : Refika Aditama.

Jain,Nandita .Wendy Lama.Renzino Lepcha. 2000. Community-based Tourism for Conservation and Development : A Resource kit. The Mountain Institute. Washington, USA.

James, Spillane., J..1982. Pariwisata Indonesia, Sejarah dan Prospeknya. Surabaya : Pustaka Binaman.

Leiper, P. 1990. Tourism Management. RMIT, Collingwood, Victoria.

Millet., John., D.1954. Management In The Public Service : the Quest For Effective Performance.New York :McGraw - Hill Book Company.

Mubyanto. 1997. Ekonomi Pancasila Lintas Pemikiran.Jakarta : Aditya Media.

Pidarta, Made. 2004.Manajemen Pendidikan Indonesia.Jakarta : Rineka Cipta.

Pitana., I Gede. 2005.Sosiologi Pariwisata.Jakarta : CV.Andi Offset.

Pendit, S., Nyoman.1999.Ilmu Pariwisata.Jakarta : Akademi Pariwisata Trisakti.

S.Margono. 1997. Metode Penelitian Pendidikan. Jakarta : Rineka Cipta

Sastrayuda, Gumelar., S.2010. Hand Out Mata Kuliah Concept Resort And Leisure, Strategi Pengembangan Dan Pengelolaan Resort And Leisure. Jakarta : Erlangga.

Soekanto, Soerjono. 1990.Sosiologi : Suatu Pengantar. Jakarta : Rajawali Pers. 
Vol. 5 No 1, 2017

Sugiyono. 2004. Metode Penelitian. Bandung : CV.Alfabeta. Sugiyono. 2009. Metode Penelitian. Bandung : CV.Alfabeta. Strauss, A dan Corbin, J. 2009. Dasar Dasar Penelitian Kualitatif. Yogyakarta : Pustaka Pelajar.

Tosun., C. 2006. Expected Nature of Community Participation In Tourism Development.Turkey : School Of Tourism and Hotel Management, Mustafa Kemal University, Tourism Management.

WTO ( World Tourism Organisation ). 2005.Tourism Barometers.Madrid : WTO.

Yeni Susanti. 2012. Partisipasi Masyarakat Lokal Dalam Pengembangan Objek Wisata Goa Tabuhan Sebagai Daerah Tujuan Wisata (Tourist Destination Area) Di Desa Wareng Kecamatan Punung Kabupaten Pacitan.Surakarta : Universitas Sebelas Maret.

http : www.kutaselatan.badungkab.go.id 